\title{
Do company-owned academic patents influence firm performance? Evidence from the Italian industry
}

\author{
Giovanni Cerulli $^{3} \cdot$ Giovanni Marin $^{4} \cdot$ Eleonora Pierucci $^{1,2,3}$ (D) Bianca Poti $^{3}$
}

Accepted: 16 December 2020 / Published online: 6 February 2021

(c) The Author(s) 2021

\begin{abstract}
We document that firms holding academic patents in their portfolios perform better in terms of market power since they benefit from academic knowledge spillovers generated by academic patents. On the other hand, we detect a negative effect on firms' short-term profitability imputable to a larger fixed cost associated to the acquisition and exploitation of these patents. In terms of policy, our analysis suggests focusing on company-owned academic patents. A set of economic incentives dedicated to university-industry knowledge transfer through academic patents could support integration between basic and applied research.
\end{abstract}

Keywords Company-owned academic patents $\cdot$ Firm profitability $\cdot$ Mark-up

JEL Codes $\mathrm{L} 1 \cdot \mathrm{L} 25 \cdot \mathrm{O} 31 \cdot \mathrm{O} 34$

\section{Introduction}

Economic literature has documented that patenting can be associated with changes in economic activity at firm level. Indeed, there is extensive mixed empirical evidence on the impact of patents on several measures of firm performance, such as growth (Andrews et al. 2014), survival (Wagner and Cockburn 2010), market value (Artz et al. 2010), firm-level productivity (Bloom and van Reenen 2002), and likelihood of obtaining venture capital and securing liquidity (Hall and Haroff 2012).

Firm portfolio can be constituted by either corporate or academic patents, the latter being inventions where at least one of the inventors is affiliated to a University. While large attention has been devoted to the technology transfer aspects of academic patents (for

Eleonora Pierucci

eleonora.pierucci@uniroma3.it

1 Department of Economics, Roma Tre University, Rome, Italy

2 Rossi-Doria Centre, Rome, Italy

3 IRCrES-CNR, Rome, Italy

4 University of Urbino "Carlo Bo", Urbino, Italy 
instance, Crescenzi et al. 2017; Quatraro and Scandura 2019), there is limited evidence on their impact on firm's performance.

Our contribution is to investigate the economic effect of company-owned academic patents on firm performance. By focusing on patenting firms, we explore the impact of academic patents held in firm's portfolio on firm's market power and profitability (as measured by mark-up and profitability indices). According to the literature, we assume that academic patents may generate differential results compared to non-academic patents due to their specific characteristics of introducing companies into more advanced scientific fields (Czarnitzki et al. 2011; Lissoni et al. 2013) which allow firms to exploit academic knowledge spillovers.

Preliminary, we explore the capability of patenting firms to better perform in terms of mark-up with respect to non-patenting firms to better characterize our sample of patenting firms and disentangle whether a different performance pattern emerges in the two groups of our sample.

The policy aspect linked to our work concerns new approaches to research and innovation policy that reward firms, namely, small- and medium-sized firms patenting their innovations and managing their patent portfolios. These policies assess firms' intangible assets relevance (e.g., number of families, of country extension), and firms' innovative projects. Possible consequences of our analysis in terms of policy is the introduction of a focus on the presence of academic patents in firms' portfolio to support integration between basic and applied research.

We use a large sample of Italian firms based on the dataset developed by Lotti and Marin (2013) merged with the APE-INV dataset collected by Lissoni et al. (2013). ${ }^{1}$

When we analyze the impact of company-owned academic patents on firm performance as measured by mark-up, return on asset (ROA), and return on equity (ROE) indices, we clearly document a significant positive impact on market power. Conversely, results on profitability indices indicate lower profitability of academic patenting. Results on mark-up are consistent with the benefits that firms can derive from accessing academic knowledge spillovers which allow for a more effective, wide and deep R\&D activity. With regard to profitability, our findings can be justified by the presence of larger asset costs required by new process and product that in the case of academic patents are due to their wider scope and breath.

The paper is organized as follows: Sect. 2 reviews the literature and presents the characters of academic patents in our sample; Sect. 3 introduces the research hypotheses; Sect. 4 describes the dataset; Sect. 5 outlines the empirical strategy; and Sect. 6 provides details on variables and descriptive statistics. Results are discussed in Sect. 6; Sect. 7 provides final discussion and remarks.

\footnotetext{
1 We focus on the Italian case that in terms of academic patenting and its industrial ownership is representative of European trends, and notable per se as witnessed by the considerable scholarly attention that have attracted (Geuna and Rossi 2011; Lissoni 2012; Kochenkova et al. 2016). Italy is characterized by an industrial system with a prevalence of small- and medium-sized firms and is affected by a macro regional economic disparity, where the south has a dramatically limited patent presence and firms are very often subsidiaries of companies located elsewhere. For this reason, we focus on a large sample of firms concentrated in the northern regions of Italy.
} 


\section{Do firms benefit from patenting with academic inventors?}

In this section we briefly review the literature concerning academic patenting, paying attention to the specific characters of academic patents within firms' portfolio.

Inventions based on academic research are considered a critical driver of innovation activities and policymakers often regard academic patents as a crucial tool of technology transfer (Lissoni and Montobbio 2015). Science provides beneficial effects to industry because it supplies guidance for industrial research by pointing out promising avenues for future technology development (Fleming and Sorenson 2004; Dasgupta and David 1994; Hall et al. 2003; Crespi et al. 2010; Henderson et al. 1998). Moreover, industry-science links benefit innovative product sales (Beise and Stahl 1999; Belderbos et al. 2004), R\&D productivity (Henderson et al. 1998), and reduced labor cost (Stern 2004). Peeters et al. (2020) demonstrate that academic involvement in patenting is related to more science infusion and more important innovative performance (measured by the number of references made to scientific literature). Their findings show that firms undertake university-industry collaborations to create new options in high-opportunity, high-risk activities (see among others, Hagedoorn et al. 2000) and attempt to create the next generation of products. In the same vein, Czarnitzki et al. (2012) study the characteristics of academic patents assigned to the corporate sector and show that they are less complex than academic patents owned by universities, signaling that they are more "important" in terms of application. Similarly, Sterzi et al. (2019) found that academic inventions held in firms' portfolios, relative to those assigned to universities, have a higher commercial potential.

The question regarding the relative value of academic patents owned by firms remains partially unanswered (Geuna and Rossi 2011; Lissoni 2012). Despite the limited evidence, a recent stream of literature has explored the relative value of academic patents versus nonacademic patents owned by the same firm (Ljungberg et al. 2013). Notably, these studies have focused on the value of firm-owned academic patents compared with corporate patents (Czarnitzki et al. 2011) and on the relationship between ownership of academic patents and their value (Crespi et al. 2010; Czarnitzki et al. 2011, 2012; Sterzi 2013). Another recent stream of literature investigates the difference in the short- and long-term values of firms' academic patents (Sterzi 2013; Czarnitzki et al. 2012). In particular, long-term citations were observed to indicate that patents are more "science-based" (Sampat et al. $2003),{ }^{2}$ coherently with the idea that academic inventors conduct more basic research (Trajtenberg et al. 1997). This suggests that firms owning academic patents should have comparative advantage in the long run.

The value and nature of firms' academic and non-academic patents reflect two opposite influences. While firms are more oriented to applied research, focusing on short-term returns, academic inventors are assumed to have a different orientation because they are trained and incentivized to conduct more basic research. Hence, patents from academic inventors' activities should have broader applications than inventions from corporate research (Trajtenberg et al. 1997; Czarnitzki et al. 2009).

Company-owned academic patents reflect the orientation of academics and show different effects in the short and long term: more science-based patents are more related to long-term citations and return than corporate patents (Czarnitzki et al. 2012; Sterzi 2013).

\footnotetext{
${ }^{2}$ Patent value is generally assessed through forward citations (Henderson et al. 1998; Sapsalis et al. 2006; Czarnitzki et al. 2011; Sterzi 2013).
} 
Peeters et al. (2020), by building on more recent scientific discoveries and emerging technologies, conjecture that much of the academic contribution is situated in the enlargement of the capacity of firms to engage in exploration, essential for their mid- to long-term innovation activities (Nelson and Winter 1982; Dosi 1988; March 1991; Rosenkopf and Nerkar 2001; Ahuja and Lampert 2001; Lester and Piore 2004).

Summing up, the literature related to academic patents presents two main strands. The first goes beyond the pure comparison between public- and private-owned patents to compare and contrast the characteristics among business-owned patents (either co-invented or not with academics). The second strand investigates the impact of academic patents on firms' inventive efforts. In this framework, the literature well depicts how science is beneficial to industry through spillovers springing from academic patents that can produce positive effects on several variables. However, there is still a dramatic limited empirical evidence on the impact of academic patents on firm performance. Our contribution aims to fill this gap in the literature by investigating the effects of business-owned academic patents on firms' market power and profitability. ${ }^{3}$

\subsection{The characters of academic patents}

As a preliminary step of our analysis, we evaluated how the characters of corporate and academic patents differ within the sample of patents owned by Italian firms. Data on various dimensions of patent quality are from the OECD Patent Quality Dataset (Squicciarini et al. 2013). ${ }^{4}$ We used ten different indicators (see Table 1). ${ }^{5}$

To compare academic to non-academic patents we ran OLS regressions, controlling for priority year, with our measures of patent quality as a dependent variable and a dummy for academic patents as independent variable. We used indicators normalized within 35 technology fields (see Squicciarini et al. 2013).

Overall, we observe a "premium" of academic versus non-academic patents in terms of patent scope, number of claims, citations to non-patent literature, and backward citations. Patent's scope represents the technological breadth of patents, that is defined in terms of IPC classes the invention is allocated to (it can significantly affect firm's value). Similarly, the number of claims also reflects the technological breadth of patents as well as the expected patent fee and market value: the higher the number of claims, the higher the expected value of a patent. Citations to non-patent literature provide how close a patented invention is to scientific knowledge and depict the proximity of technological and scientific developments (Callaert et al. 2006). Finally, academic patents are observed to rely on a smaller number of backward citations, suggesting a lower contribution of past knowledge at the basis of the invention. For the other quality indicators, no statistically significant difference emerges between academic and non-academic patents.

\footnotetext{
${ }^{3}$ In our research hypotheses and in the empirical investigation, by academic patent we mean a patent that has at least one academic scientist among its inventors.

4 In this paper, technological fields are defined according to Schmoch's (2008) classification (as updated in 2010 and 2011), which relies on the International Patent Classification (IPC) codes in the patent documents. This taxonomy features six main technology sectors subdivided into 35 fields of balanced size and structured to maximize within-sector homogeneity and across-sector differences.

${ }^{5}$ Forward citations (5 years); Forward citations (7 years); Patent scope; Backward citations; Citations to non-patent literature; Number of claims; Originality; Radicalness; Patent family size; Renewals.
} 
Table 1 Comparison of patent quality for academic and nonacademic patents

\begin{tabular}{llll}
\hline Patent quality indicators: & $\begin{array}{l}\text { Academic } \\
\text { patents } \\
\text { (dummy) }\end{array}$ & (SE) & $\mathrm{N}$ \\
\hline Forward citations (5 years) & 0.0870 & $(0.0783)$ & 30,651 \\
Forward citations (7 years) & 0.113 & $(0.0740)$ & 30,651 \\
Patent scope & $0.0128 *$ & $(0.00696)$ & 30,612 \\
Backward citations & $-0.267 * * *$ & $(0.0278)$ & 30,651 \\
Citations to non-patent literature & $0.592 * * *$ & $(0.115)$ & 30,651 \\
Number of claims & $0.0559 * * *$ & $(0.0184)$ & 30,651 \\
Originality & -0.0114 & $(0.0106)$ & 30,084 \\
Radicalness & 0.0169 & $(0.0245)$ & 30,088 \\
Patent family size & -0.00115 & $(0.0178)$ & 30,651 \\
Renewals & -0.00362 & $(0.0144)$ & 28,521 \\
\hline
\end{tabular}

OLS regressions on patents of Italian companies for the period 19962007 (priority year). Indicators are normalized by 35 technology classes. All regressions include 3-digit IPC class dummies and dummies for the year of priority of the patent. Robust standard errors in parenthesis

$* p<0.1, * * p<0.05, * * * p<0.01$

To sum up, from the study of the characters of patents held by Italian firms, we can find a clear descriptive evidence on the larger breadth and depth of knowledge embedded in academic patents as well as on higher potential knowledge spillovers in technology (OECD 2009).

\section{Research hypotheses}

The main objective of this paper is to assess the role of company-owned academic patents on firm's market power and profitability. Dasgupta and David (1994) assert that the scientific and technological communities follow different incentives and motivations, but their interrelations reinforce and enrich one another.

Academic knowledge embedded into an academic patent naturally implies positive knowledge spillovers for those firms owning these patents in their portfolio, potentially increasing output and its value without additional costs. Furthermore, firms' ownership of academic patents may imply interactions between firms and academic researchers either through research collaborations or through direct personal exchanges which often occur with the use of an academic patent. Spillovers deriving from the academic knowledge content of patents, as well as from university-industry potential interactions, can produce a positive effect on market power. ${ }^{6}$ For instance, Peeters et al. (2020) have referred to survey data on academic and industrial research collaborations which corroborate the contribution of university research to the development of new products and processes (Faems et al. 2005), generating higher sales and cost savings (Mansfield 1995, 1998).

\footnotetext{
${ }^{6}$ In this paper the mark up is calculated following the approach of De Loecker and Warzynski (2012).
} 
Consequently, our hypothesis on the effects of business-owned academic patents on mark-up lies predominantly on the academic knowledge and technological insights embedded in academic patents that produce positive spillovers for firms regardless the type of university-industry interaction and its determinants. Thus, we formulate the hypothesis that academic patents generate different results compared with non-academic patents in terms of market power and profitability ${ }^{7}$ :

H1 Ownership of academic patents allows firms to gain a stronger position in terms of mark-up than non-academic patents.

The literature points out the somehow unexpected negative relationship between patents and profits (for instance, considering indices such as ROA). One of the reasoning for this outcome is based on the additional investments required to realize such innovation activity. Indeed, if the reduction of variable costs determined by knowledge and technological spillovers embedded in academic patents can generate the enlargement of the distance between price and marginal cost (raise in markup), fixed costs associated to co-invention or acquisition of academic patents can reduce profitability indices in the short run.

Firms can experience in the short run a negative effect on profitability (Hanel and StPierre 2002), particularly in science-based industry, since additional costs associated to patenting activity are captured by the denominators of the profitability indices (Grabowski et al. 2002). Theoretically, academic patents should have a positive impact on economic returns since they are characterized by a larger scope that implies a higher number of possible applications. However, as a consequence of larger patents' scope, investments and costs may raise even more (comparatively to corporate patents), thus cost recovery may be much longer. Furthermore, a negative impact on profitability, can be associated to adjustment costs to improve firm's absorptive capacity, since academic knowledge rooted into academic patent may be far from firm's competences. Indeed, adjustment costs require also longer time horizon to get a positive economic return: more science-based patents are more related to long-term returns than corporate patents (Czarnitzki et al. 2012; Sterzi 2013). While additional investments to realize the innovation occur at early stages of the research and development process, their return is diluted over many years ahead. As investments enter the denominator of ROA, profits attributable to innovation enter the numerator; the ratio could decrease at first and then increase in later years as returns are realized (numerator) and assets, including innovation investments, depreciate (denominator).

Therefore, in summary, if we might expect a positive effect of business-owned academic patents on markup, in the short run, these patents can determine a stronger negative effect on profitability as compared to corporate patents. All this leads to formulate our second hypothesis:

H2 Ownership of academic patents determines lower firms' profitability in the short term compared to non-academic patents.

\footnotetext{
${ }^{7}$ Behind collaborations/interactions there might be a number of different motivations and determinants, however they are not the focus of our paper and we do not investigate what may drive firms to collaborate with university or to own academic patent.
} 


\section{Data}

The APE-INV dataset collected by Lissoni et al. (2013) contains all patent applications filed at the EPO from 1978 to 2009 and signed by inventors with both an Italian address and a tenured position in an Italian university in 2000, 2005, and 2009. We retain only the applications with priority dates between 1996 and 2007. The APE-INV dataset includes patent applications at the EPO by type of first applicant (applicant of the priority patent in the DOCDB family) and priority year. Patents are defined as academic if at least one inventor was a tenured faculty member of an Italian university at the time of filing, based on inventor-faculty name matching followed by a survey to control data (see Lissoni et al. 2013, for the methodology). In APE-INV, Lissoni et al. (2013) do not consider all patents filed before 1997 because that set of patents is likely to include many academic patents from inventors who retired in 2000, and thus would escape the APE-INV data collection effort.

We focus on business-owned academic patents. To this purpose, we employ the matching between corporate applicants and Italian company names (from the AIDA database of Bureau van Dijk) developed by Lotti and Marin (2013). ${ }^{8}$ The sample is 30,662 EPO patent applications by 6,504 Italian firms for the period 1996-2007. Matching allows us to link patent applications to the corresponding firms' indicators of performance based on balance sheet and income statement information available in the AIDA database. ${ }^{9}$

The distribution of patents across five technology fields (electrical engineering, instruments, chemistry, mechanical engineering, other fields, see Schmoch 2008) is reported in Table 2 (Panel A comprises all patents, Panel B comprises academic patents).

The overall number of patents is 19,337, of which almost a half (44\%) refers to patents in mechanical engineering. By contrast, academic patents are mainly concentrated in the chemistry field (approximately $50 \%$ of total academic patents). The specificity of this field is the complexity of the innovation activity, which is peculiar for a science-based industry and characterized by significantly long processes and remarkably high costs (Sternitzke 2010). Consequently, profitability is more likely to occur in the long run, and short-run returns can be more than compensated by higher costs. This peculiarity of the sample represents a strength. The science-based nature of this industry makes its growth and profitability strictly dependent on successful research. Discovery and development of drugs, for example, require a great amount of human and financial resources, therefore biopharmaceutical industry has the vital need to acquire external knowledge often engaging with university and public research centers to exploit knowledge (often public) spillovers. This

\footnotetext{
${ }^{8}$ In our dataset, APE-INV data are not attributed to firms according to the name of first applicant. They are merged with the PATSTAT-AIDA sample (Lotti and Marin 2013, where a snapshot of patent ownership for year 2012 is used to match applicant-firm names) through patent application number; therefore, what we know is that a certain patent, having among its inventors an academic, is owned by firm $i$ at time $t$. For this patent we also know the priority date, through which we construct our treatment variable. As our focus is not the investigation of the effect of university-industry collaboration on patenting activity, in this setup, our research hypotheses are not affected by a possible change in patent ownership. An academic patent is per se a knowledge and technology transfer mode that allows owning firms to acquire and exploit academic research regardless the fact that this is or not the result of university-firm joint research.

9 These two good-quality datasets (i.e. Lotti and Marin 2013 and APE-INV) provide a unique tool to investigate the research questions at hand on a European country. Furthermore, given that the two datasets have already been largely employed (separately) in academic research, they are scientifically validated, providing reliability to our analysis (for example, Crescenzi et al. 2017; Leoncini et al. 2019; Quatraro and Scandura 2019; Sterzi et al. 2019; Lotti and Marin 2013; Gagliardi et al. 2016; Liberati et al. 2016).
} 
Table 2 Patents by priority year and technology fields (IPC classes)

Electrical engineer- Instruments Chemistry (includ- Mechanical engi- Other fields Total ing ing pharmaceuti- neering cals)

\begin{tabular}{|c|c|c|c|c|c|c|}
\hline \multicolumn{7}{|c|}{ Panel A: All patents } \\
\hline 1996 & $235(18 \%)$ & $113(9 \%)$ & $278(22 \%)$ & $519(41 \%)$ & $131(10 \%)$ & 1276 \\
\hline 1997 & $180(14 \%)$ & $95(7 \%)$ & $292(22 \%)$ & $576(43 \%)$ & $188(14 \%)$ & 1331 \\
\hline 1998 & $237(17 \%)$ & $112(8 \%)$ & $348(25 \%)$ & $587(41 \%)$ & $133(9 \%)$ & 1417 \\
\hline 1999 & $205(13 \%)$ & $126(8 \%)$ & $383(24 \%)$ & $654(41 \%)$ & $212(13 \%)$ & 1580 \\
\hline 2000 & $219(14 \%)$ & $144(9 \%)$ & $350(22 \%)$ & $693(43 \%)$ & $203(13 \%)$ & 1609 \\
\hline 2001 & $186(11 \%)$ & $126(8 \%)$ & $377(23 \%)$ & $769(46 \%)$ & $216(13 \%)$ & 1674 \\
\hline 2002 & $214(12 \%)$ & $157(9 \%)$ & $395(22 \%)$ & $748(42 \%)$ & $267(15 \%)$ & 1781 \\
\hline 2003 & $237(14 \%)$ & $152(9 \%)$ & $331(20 \%)$ & $746(44 \%)$ & $213(13 \%)$ & 1679 \\
\hline 2004 & $255(14 \%)$ & $159(9 \%)$ & $353(20 \%)$ & $760(43 \%)$ & $245(14 \%)$ & 1772 \\
\hline 2005 & $262(15 \%)$ & $147(8 \%)$ & $326(18 \%)$ & $771(44 \%)$ & $262(15 \%)$ & 1768 \\
\hline 2006 & $216(12 \%)$ & $173(10 \%)$ & $285(16 \%)$ & $853(48 \%)$ & $264(15 \%)$ & 1791 \\
\hline 2007 & $178(11 \%)$ & $159(10 \%)$ & $238(14 \%)$ & $825(50 \%)$ & $259(16 \%)$ & 1659 \\
\hline Total & $2624(14 \%)$ & $1663(9 \%)$ & $3956(20 \%)$ & $8501(44 \%)$ & $2593(13 \%)$ & 19,337 \\
\hline \multicolumn{7}{|c|}{ Panel B: Academic patents } \\
\hline 1996 & $31(37 \%)$ & $8(10 \%)$ & $30(36 \%)$ & $13(15 \%)$ & $2(2 \%)$ & 84 \\
\hline 1997 & $26(35 \%)$ & $7(9 \%)$ & $30(40 \%)$ & $11(15 \%)$ & $1(1 \%)$ & 75 \\
\hline 1998 & $23(33 \%)$ & $5(7 \%)$ & $32(46 \%)$ & $7(10 \%)$ & $2(3 \%)$ & 69 \\
\hline 1999 & $17(19 \%)$ & $12(13 \%)$ & $48(53 \%)$ & $11(12 \%)$ & $2(2 \%)$ & 90 \\
\hline 2000 & $28(31 \%)$ & $14(16 \%)$ & $37(42 \%)$ & $8(9 \%)$ & $2(2 \%)$ & 89 \\
\hline 2001 & $16(20 \%)$ & $11(14 \%)$ & $48(59 \%)$ & $4(5 \%)$ & $2(2 \%)$ & 81 \\
\hline 2002 & $23(26 \%)$ & $9(10 \%)$ & $50(56 \%)$ & $6(7 \%)$ & $1(1 \%)$ & 89 \\
\hline 2003 & $16(25 \%)$ & $15(23 \%)$ & $29(45 \%)$ & $5(8 \%)$ & $0(0 \%)$ & 65 \\
\hline 2004 & $12(20 \%)$ & $4(7 \%)$ & $36(61 \%)$ & $4(7 \%)$ & $3(5 \%)$ & 59 \\
\hline 2005 & $12(19 \%)$ & $8(13 \%)$ & $32(51 \%)$ & $10(16 \%)$ & $1(2 \%)$ & 63 \\
\hline 2006 & $18(27 \%)$ & $9(13 \%)$ & $27(40 \%)$ & $13(19 \%)$ & $0(0 \%)$ & 67 \\
\hline 2007 & $3(9 \%)$ & $7(21 \%)$ & $9(27 \%)$ & $14(42 \%)$ & $0(0 \%)$ & 33 \\
\hline Total & $225(26 \%)$ & $109(13 \%)$ & $408(47 \%)$ & $106(12 \%)$ & $16(2 \%)$ & 864 \\
\hline
\end{tabular}

The table reports the number of patents and, in squared brackets, patent shares by year and technological field

applies, though to a lesser extent, to the more traditional chemical sector too (Giunta et al. 2016). These factors explain the reason why this industry can be particularly suitable to investigate our research questions.

Table 3 reports the distribution of patenting firms (academic and non-academic) across different regions and size classes. Notably, academic patents in micro- small-, and mediumsized firms are almost evenly distributed, and the role of micro- and small-firms on the total of academic patents is significant (approximately $44 \%$ ). ${ }^{10}$

\footnotetext{
10 The South of Italy has a dramatically limited presence of patents. In order to avoid the use of such misleading information, we use a sample of firms concentrated in the Northern regions of Italy. Indeed, including the South would induce a bias to our effect's estimates due to the fact that Southern companies are a very small fraction of the total and the large majority of them is made of subsidiaries of companies located elsewhere (where, potentially, the returns of patents will eventually appear). Just to give an example, in
} 


\section{Estimation strategy}

We first set out our empirical analysis by showing to what extent patenting firms obtain a stronger position on the market with respect to firms that do not patent. To this aim, we employ a dynamic difference-in-differences model as proposed by Cerulli and Ventura (2019). Subsequently, we focus on testing both H1 and H2 -i.e. how ownership of academic patents impact on firm's market positioning and profitability; in this part, we use a regression adjustment and a matching approach.

\subsection{Regression adjustment and matching}

The regression adjustment (RA) approach is a parametric alternative to matching when one aims at measuring the impact of a treatment on an outcome. Compared to matching, however, RA is more suited to obtain the idiosyncratic (i.e., firm-specific) effect of the treatment as it directly estimates the $\operatorname{ATET}(\mathrm{X})$, or conditional average treatment effect on the treated. In particular, analyzing the distribution of ATET(X) allows to investigate the overall effect of the academic patenting event beyond the average effect obtained by implementing matching. Indeed, a single matching estimate might be poorly informative on the entire causal relationship between academic patenting and firm economic performance. Below we provide a concise illustration of this method.

Under the selection of a firm's observable characteristics $\mathbf{x}_{i}$, company $i$ 's idiosyncratic average treatment effect for an outcome $Y$ (i.e., market power or a profitability measure) is

$$
\operatorname{ATE}\left(\mathbf{x}_{i}\right)=m_{1}\left(\mathbf{x}_{i}\right)-m_{0}\left(\mathbf{x}_{i}\right)
$$

where $m_{1}\left(\mathbf{x}_{i}\right)=\mathrm{E}\left(Y_{i} \mid \mathbf{x}_{i}, D_{i}=1\right)$ and $m_{0}\left(\mathbf{x}_{i}\right)=\mathrm{E}\left(Y_{i} \mid \mathbf{x}_{i}, D_{i}=0\right)$, with $D_{i}$ equal to the treatment variable (in our case, $D_{i}=1$ for firms filing at least one academic patent in the time considered and zero otherwise). The average treatment effects (ATE, ATET, and ATENT) are estimated using these formulas:

$$
\begin{gathered}
\widehat{\mathrm{ATE}}=\frac{1}{N} \sum_{i=1}^{N}\left[\hat{m}_{1}\left(\mathbf{x}_{i}\right)-\hat{m}_{0}\left(\mathbf{x}_{i}\right)\right] \\
\widehat{\mathrm{ATET}}=\frac{1}{N_{1}} \sum_{i=1}^{N} D_{i} \cdot\left[\hat{m}_{1}\left(\mathbf{x}_{i}\right)-\hat{m}_{0}\left(\mathbf{x}_{i}\right)\right]
\end{gathered}
$$

\footnotetext{
Footnote 10 (continued)

2008, only 18 out of 55 patenting firms in the South are "pure" Southern companies, and these figures would shrink even further if we consider firms owning academic patents. Thus, they configure as "sparse" units, and the sensitivity of our results obtained by including them indicates that they are more outliers than inlier units. For this reason, especially for this "small numbers" consideration, we deem it better for our analysis to consider/compare just companies located in the North. Moreover, excluding the few Southern companies form our estimation sample, makes our matching procedure more balanced than otherwise. In conclusion, our empirical exercise is able to catch the most of the investigated effect, without introducing noisy elements hardly extricable.
} 


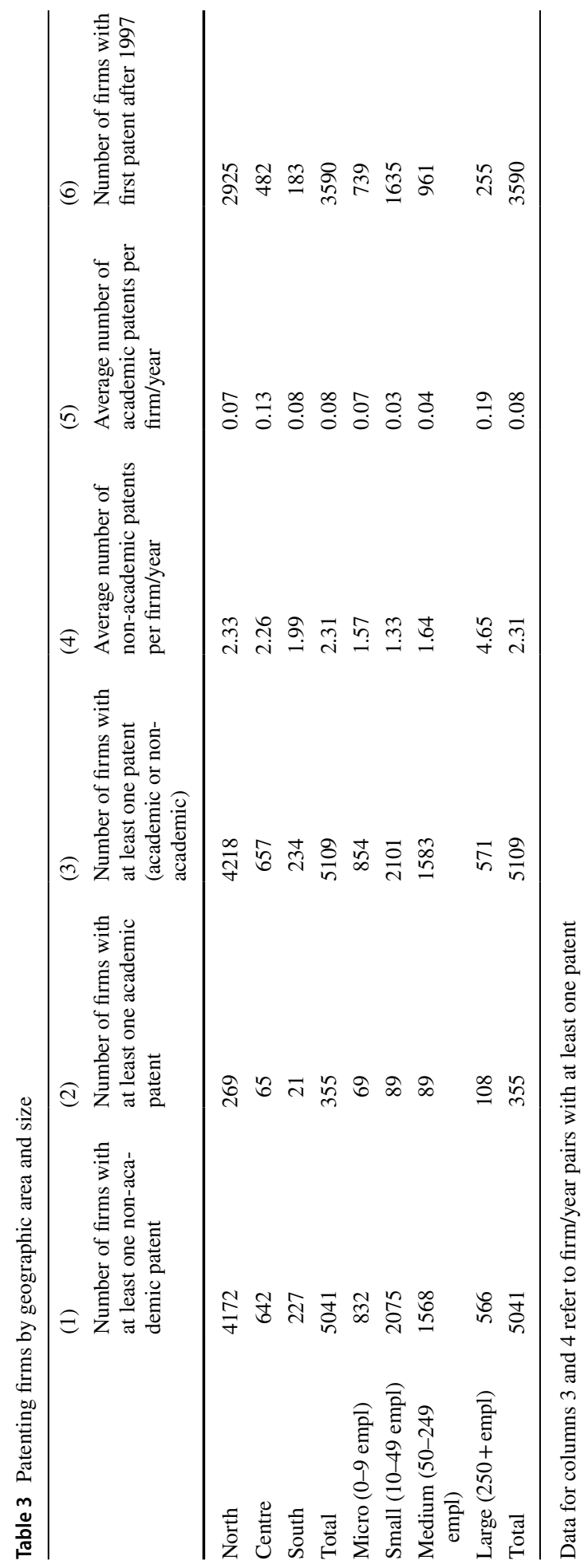




$$
\widehat{\operatorname{ATENT}}=\frac{1}{N_{0}} \sum_{i=1}^{N}\left(1-D_{i}\right) \cdot\left[\hat{m}_{1}\left(\mathbf{x}_{i}\right)-\hat{m}_{0}\left(\mathbf{x}_{i}\right)\right]
$$

where "hat" refers to an estimator of $m_{1}(\mathbf{x})$ and $m_{0}(\mathbf{x})$.

Both $m_{1}(\mathbf{x})$ and $m_{0}(\mathbf{x})$ can be estimated either parametrically or non-parametrically. Using a parametric model (as a linear one) corresponds to the regression-adjustment approach. Conversely, adopting nearest neighbor regression estimation of $m_{1}(\mathbf{x})$ and $m_{0}(\mathbf{x})$ corresponds to nearest neighbor matching (Cerulli 2015). We considered both approaches in the results section.

\subsection{Dynamic difference-in-differences}

The event "first year to patent" is a time-variant treatment variable. We attempt to assess whether this treatment affected firms' market position with some delays or if anticipatory effects occurred. For this purpose, we indicate by $D_{i t}$ the "first year to patent" binary treatment indicator for individual $i$ at time $t$ :

$$
D_{i t}=\left\{\begin{array}{l}
1 \text { if unit } i \text { is treated at time } t \\
0 \text { if unit } i \text { is untreated at time } t
\end{array}\right.
$$

and assume, just for illustrative purposes, an outcome equation (firm market position) with one lag and one lead. The baseline regression to estimate is the following:

$$
Y_{i t}=\mu_{i t}+\beta_{-1} D_{i t-1}+\beta_{0} D_{i t}+\beta_{+1} D_{i t+1}+\gamma X_{i t}+\varepsilon_{i t}
$$

Following Autor (2003), Cerulli and Ventura (2019) show that the parameters in Eq. (5) - that extended to more than one lag and more than one lead-have a causal interpretation as average treatment effects over time in Fig. 1, where pre- and post-treatment effects are clearly visible.

If $\beta_{+1}>0$ is significant, there is a positive effect of the first patent (i.e., the treatment) at $t$ on the market position (i.e., the outcome) at $t-1$, that is, the current treatment affected past outcome (anticipatory effect). Therefore, the pretreatment period is characterized by a positive effect of current treatment.

If $\beta_{0}>0$ is significant, there is a positive effect of the first patent at $t$ on the firm market position at $t$, that is, the current treatment affected the current outcome (simultaneous effect). Therefore, the treatment period is characterized by a positive effect of the treatment administrated in the same period.

Finally, if $\beta_{-1}>0$ is significant, there is a positive effect of the first patent at $t$ on the market position of the company at $t+1$, that is, the current treatment affected future outcomes (lagged effect). Therefore, the post-treatment period is characterized by a positive effect of current treatment.

In the case of no-anticipatory effects, if all leads are jointly zero in Eq. (5), we can conclude that the so-called "common trend"- the main assumption for causal identification in this setting-holds. In this case, the post-treatment pattern can have a causal interpretation. Hence, prior to any causal conclusion regarding the future effect of treatment, we must first 


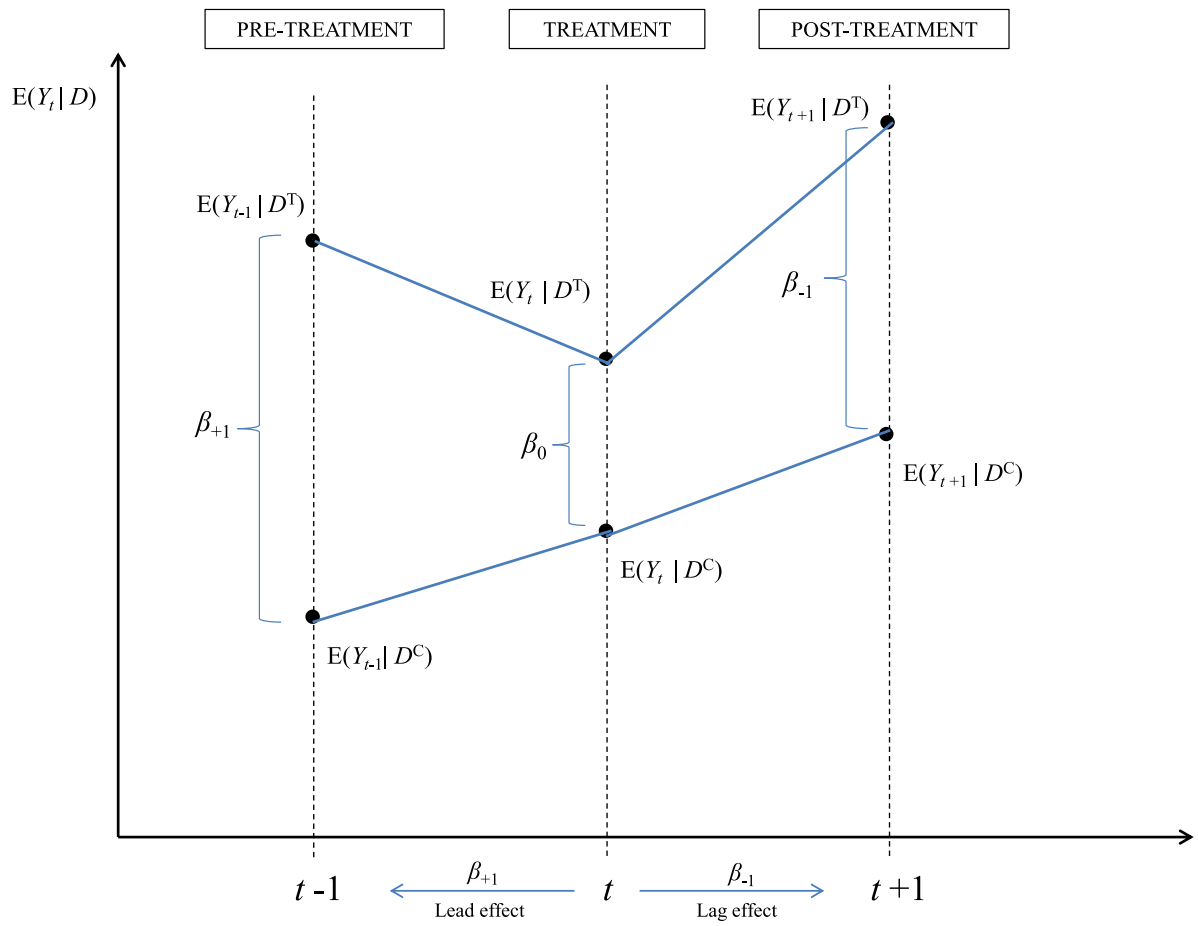

Fig. 1 Pre ( $t-1)$ and post $(t+1)$ treatment effect of a treatment performed at $t$

check for the presence of a pretreatment common trend of treated (patenting) and control (non-patenting) firms.

\section{Variables and descriptive statistics}

\subsection{Indicators of firm performance}

Firm performance is measured by indicators based on accounting information from the AIDA database, that is, our hypotheses developed in Sect. 3 refer to a likely effect of patenting strategies on firm's profitability and mark-up. Regarding profitability, we consider the ROA index and, as robustness check, the ROE index. ${ }^{11}$ The ROA index was calculated as the ratio between the earnings before interest and taxes and the book value of total asset. This index is closely related to the overall profitability of the company, whether capital is owned by shareholders or constituted by liabilities. Thus, the ROA, is supposed to be neutral regarding how the company is financed.

It is important to detail further how a profitability index is expected to react as a consequence of (innovative) investments from a purely 'accounting' viewpoint. Investments

\footnotetext{
11 ROE was calculated as the ratio between net profits and the book value of equity (including current and past retained profits) and is a proxy of the overall economic value created by the company for its shareholders in a specific year.
} 
$I$ taking place in year $t$ increase total assets by $I_{t}$ in year $t$. However, the returns of investments (in tangible or intangible capital) are expected to be distributed across several periods. Indeed, an investment is actually made if the expected net present value is larger than $I_{t}$. From an account viewpoint, $I_{t}$ enters the denominator of ROA in year $t$. However, returns from the investment will enter the numerator of ROA (positively) not only in year $t$ but also in subsequent years. Moreover, starting from year $t+1$ both the numerator and denominator of ROA would decrease by $\delta I$, that is depreciation and amortisation. This means that the time profile of ROA as a consequence of an investment is likely to have a first drop in the year of the investment $(t)$, followed by an increase in the later years (provided the investment generates enough high returns). Similar reasonings apply to the ROE index as we use it to corroborate our results.

Regarding mark-up, defined as the ratio between price and marginal cost, we have no direct indicator in accounting data. Ideally, the first best option would be to have detailed information on firm-level prices and cost functions. However, a recent paper by De Loecker and Warzynski (2012) proposes a way to estimate firm-specific mark-up starting from standard information on firms' production data available from balance sheet and income statement records. De Loecker and Warzynski (2012) assume cost-minimizing firms and the presence of both variable inputs (i.e. labor, that adjusts freely in the short term) and dynamic inputs (i.e. capital, that could be considered as a fixed input in the short term). Under these mild assumptions, they show that the mark-up $\mu_{i t}$ for firm $i$ in year $t$ can be defined as the ratio between the elasticity of value added with respect to the variable input $\left(\theta_{i t}^{L}\right)$, and the corresponding variable input share of value added $\alpha_{i t}^{L}$.

$$
\mu_{i t}=\theta_{i t}^{L} / \alpha_{i t}^{L}
$$

To estimate $\mu_{i t}$ we thus need estimates of $\theta_{i t}^{L}$ (possibly firm/year specific) as well as information on the labour share (to be further adjusted, see below). We estimate (separately for each 2-digit NACE sector) $\theta_{i t}^{L}$ by means of a value added based translog production function that accounts for the endogeneity of inputs by means of the GMM estimator proposed by Ackerberg et al. (2015). Notably, the translog production function allows the elasticity to vary across firms and years even within the same sector. In Ackerberg et al. (2015), potential value added (defined below) is a function of inputs (labor and capital): capital is assumed to be exogenous while labor is instrumented by its lagged value to limit simultaneity bias.

Regarding the denominator of the equation defining the mark-up, that is, the labor share of value added, De Loecker and Warzynski (2012) highlight that, due to the presence of the idiosyncratic error in the production function $\varepsilon_{\mathrm{it}}$, measured value added from accounting data is not the potential value added but it actually is $V A_{i t} / \exp \left(\varepsilon_{i t}\right)$. For this reason, to calculate the labor share of potential value added, we correct for this idiosyncratic component in calculating $\alpha_{i t}^{L}$. To isolate the idiosyncratic component $\varepsilon_{\text {it }}$ within a production function framework, what is needed is to split the residual into a total factor productivity (TFP) component and a truly idiosyncratic component $\varepsilon_{\mathrm{it}}$ : Ackerberg et al. (2015) suggest to estimate $\varepsilon_{i t}$ as the residual of a non-parametric estimate of value added as a function of 
inputs (labor, capital and materials, up to the third order polynomial and with all possible interactions): the idea is that while TFP is likely to be correlated to input choices, $\varepsilon_{\text {it }}$ is the part of value added with constant (zero) conditional expectation with respect to inputs $\left(E\left[\varepsilon_{\mathrm{it}} \mid L_{i t}, K_{i t}\right]=0\right)$.

\subsection{Descriptive statistics of the model's variables}

A detailed description of our variables and indicators is reported in Table 4, while descriptive statistics for our model variables in levels for the three matching exercises are shown in Table 5.

The sample of treated firms is constituted by those firms owning at least one academic patent, while untreated firms are those having only corporate patents in their portfolio. Treatment variable for testing our $\mathrm{H} 1$ and $\mathrm{H} 2$ hypotheses is First academic patent, whereas First patent is the treatment variable for our preliminary diff-in-diffs analysis (Fig. 1).

Table 4 reports definitions of the outcome variables detailed in Sect. 6.1 as well as the description of treatment variables and the set of $X$ variables. As regressors, we employ some of the most used variables in the literature to define firms' characteristics. First, we include a measure of size captured by number of employees, while as a cost measure we include labor cost. We account for firm's commitment in research activity by $R \& D$ expenditure; stock of capital allows us to control for productivity and operating capacity. Patent portfolio quality represents the average quality of patents in portfolio: inserting this variable among the control variables, we can better disentangle academic patent effect from the quality of the entire set of patents held in firm portfolio. Patent post 97 controls for having first patent in portfolio after 1997 (start date of our time sample). In all empirical exercise we control for IPC classes or NACE sectors, and include time and regional dummies.

From Panel a), considering mark-up as the outcome variable, we observe that the sample of firms displays specific characteristics: Treated firms have higher levels of stock of capital, R\&D expenditure, and mark-up compared with other patenting firms with no academic patent. By contrast, they are on average smaller than the untreated ones, with similar level of labor cost, but significantly higher minimum level that we interpreted as the presence of better-skilled workers. In Panels b) and c), where the outcome variables are, respectively, ROA and ROE, we find similar characteristics for treated firms except for the outcome variables which are lower for the treated.

In summary, firms that own academic patents are on average smaller but characterized by better economic potential because of their levels of physical and intangible capital.

\section{Results}

Evidence and arguments on the effect of patent protection on innovation-through incentive effects-and decreased competition due to temporary monopolies are mixed within the literature on economics of innovation (Artz et al. 2010; Bloom and van Reenen 2002). As a preliminary step, through a diff-in-diffs analysis, we test the capability of patenting firms to better perform in terms of mark-up with respect to non-patenting firms. We conduct this empirical exercise as a preliminary control analysis to better characterize our sample of patenting firms. 


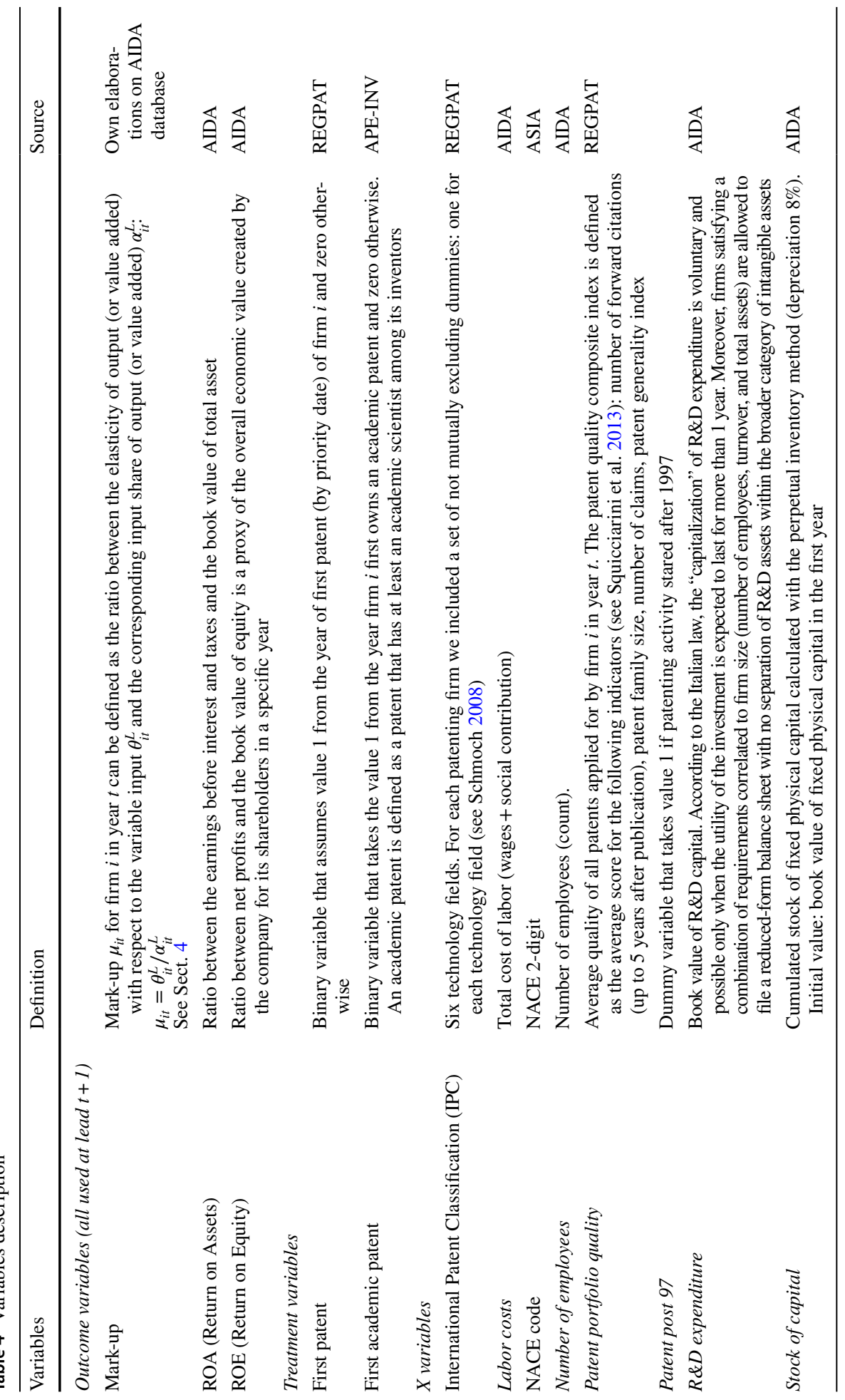




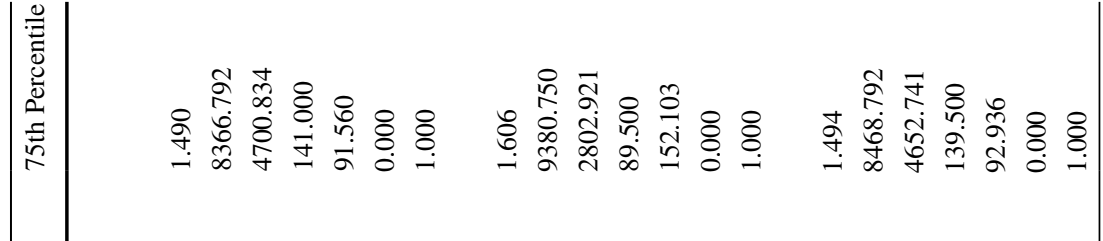

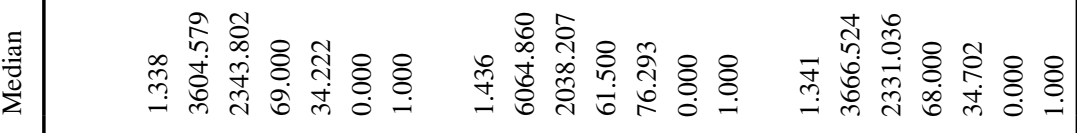

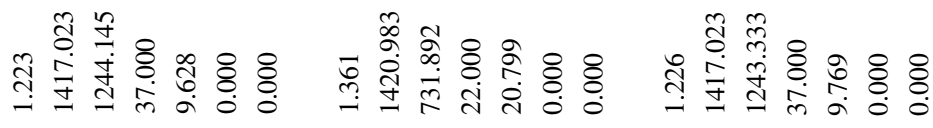

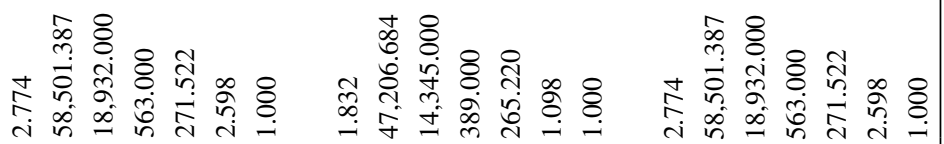

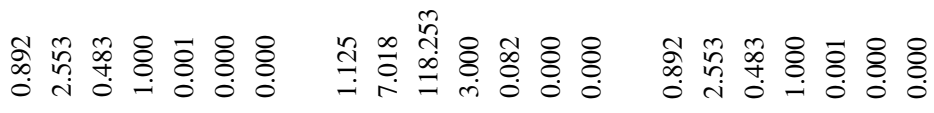

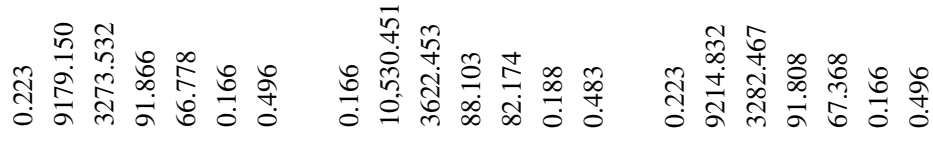

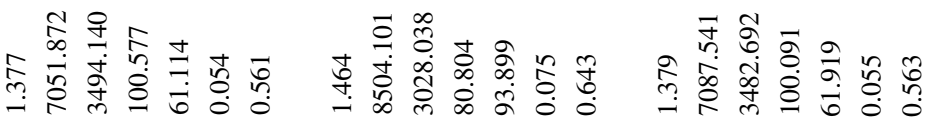

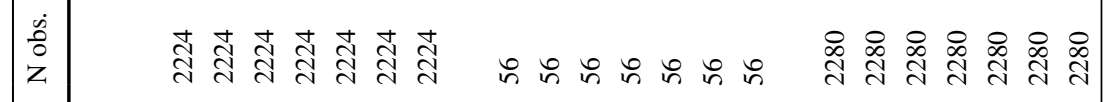

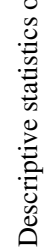

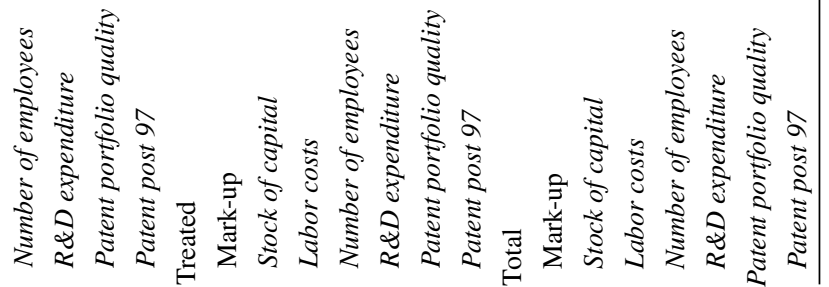$$
\frac{\substack{0 \\ \frac{0}{\pi}}}{\frac{0}{\pi}}
$$ 


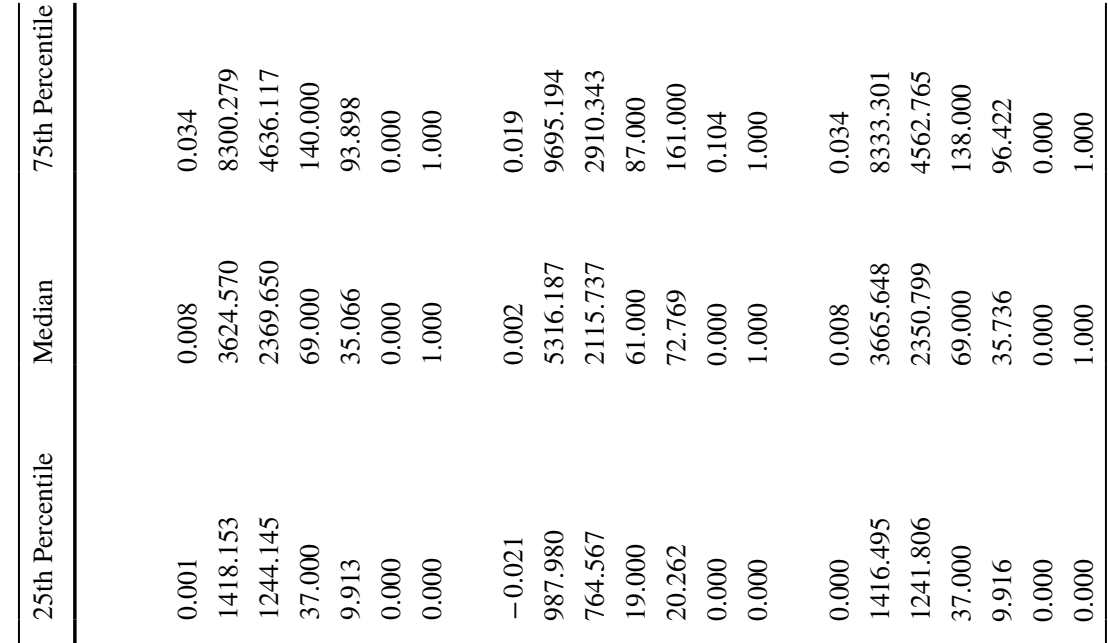

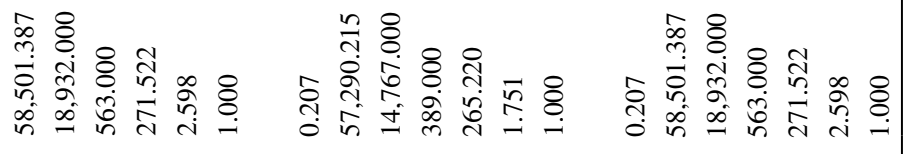

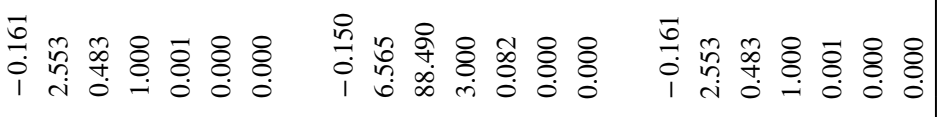

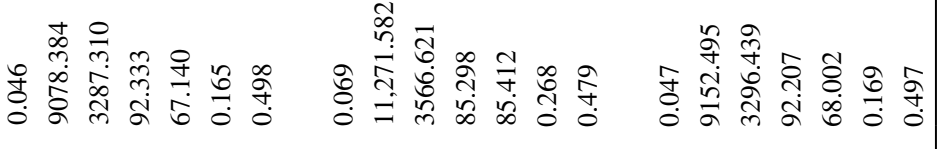

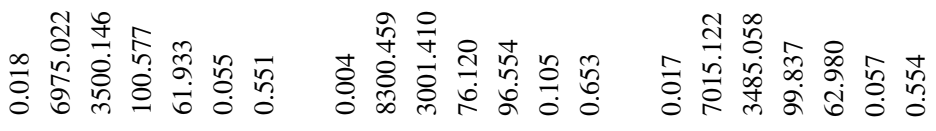

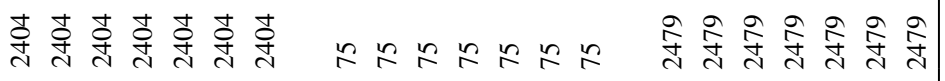

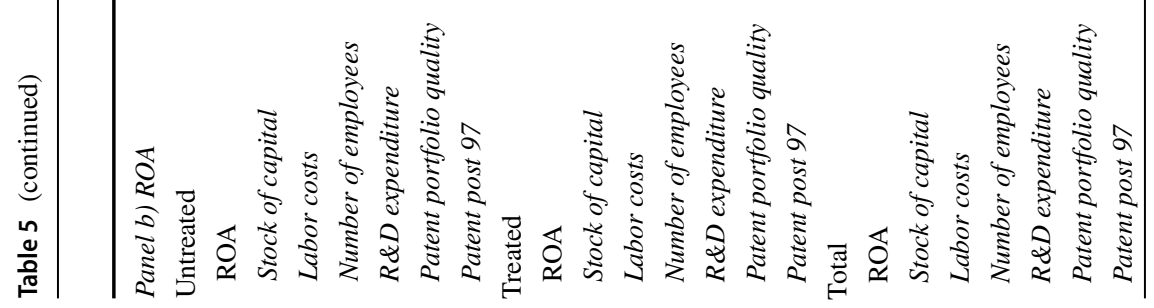




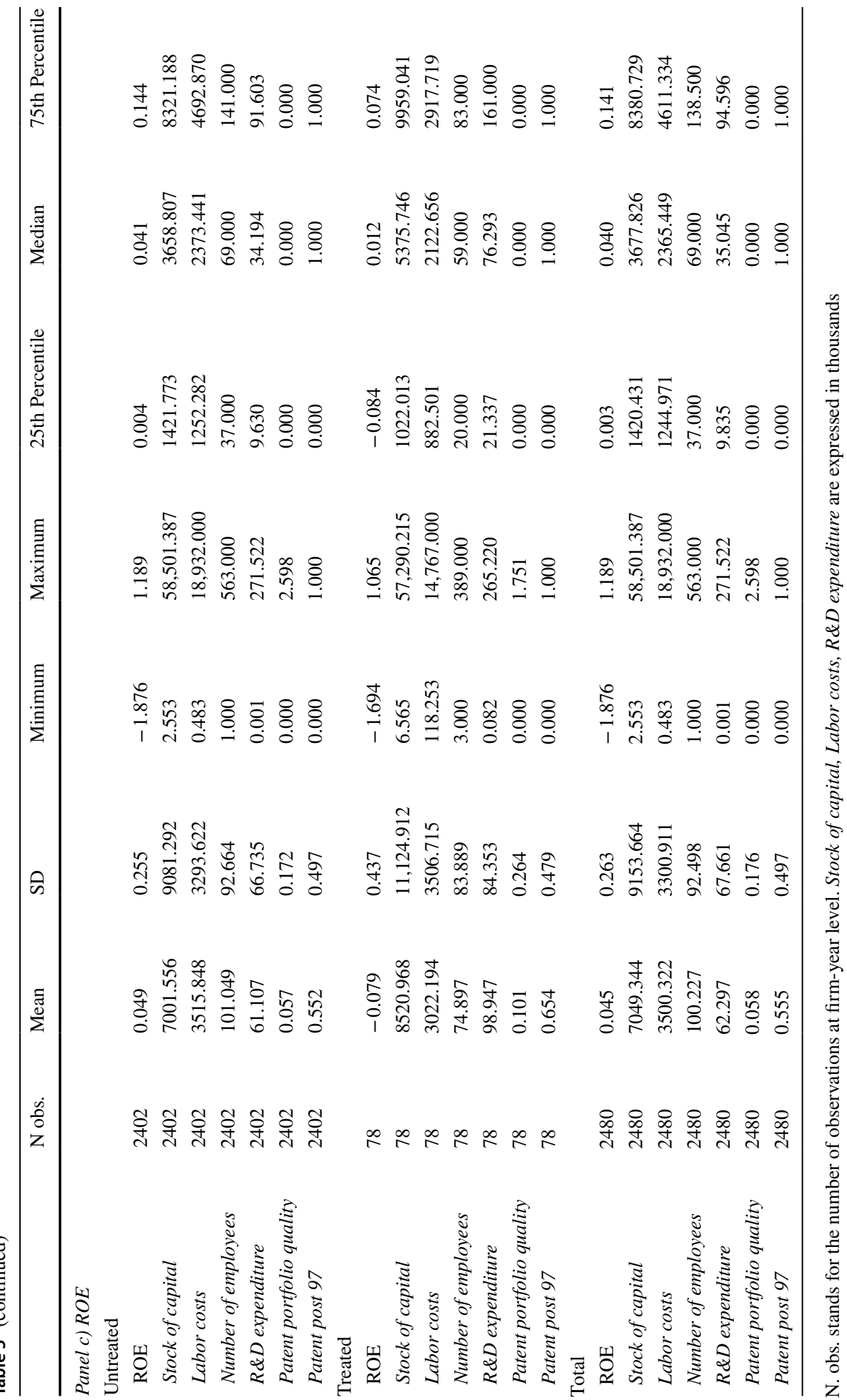


We analyze whether patenting firms obtain a stronger position on the market with respect to firms that do not patent. Given the large sample of firms and a reliable time horizon of 12 years, we could apply the dynamic difference-in-differences model outlined in the previous section. Our treatment variable is a binary variable that assumes the value 1 from the year of the first patent (by priority date) of firm $i$ and zero otherwise. Therefore, each firm is considered treated from the first time it owned a patent. Our outcome variable is the mark-up at time $\mathrm{t}+1$ (Sect. 6.1 provides a detailed description of outcome variables). As regressors, we include the log values of the stock of capital, labor cost, number of employees, $R \& D$ expenditure, patent portfolio quality. We also include regional and time dummies, and control for NACE sectors and for the presence of a first patent in portfolio after 1997 (patent post 97) in order to control for those that already had patenting activity before the start of our time sample.

Figure 2 presents the results of the dynamic difference-in-differences associated with the event of first patenting at year $t$.

This analysis allows us to detect the pre- and post- first patenting effect on the markup outcome variable. In the chart, the test of common trend assumption is passed, and the post-treatment effect is positive and significant from the year of first patenting (time $t$ in the graphs) until the third year. The chart shows an inverted-U shape of the effect pattern over the post-treatment period, entailing that the increasing market power allowed by patenting (the Schumpeterian innovation rent) fades away in a relatively short time due to competitors' imitation.

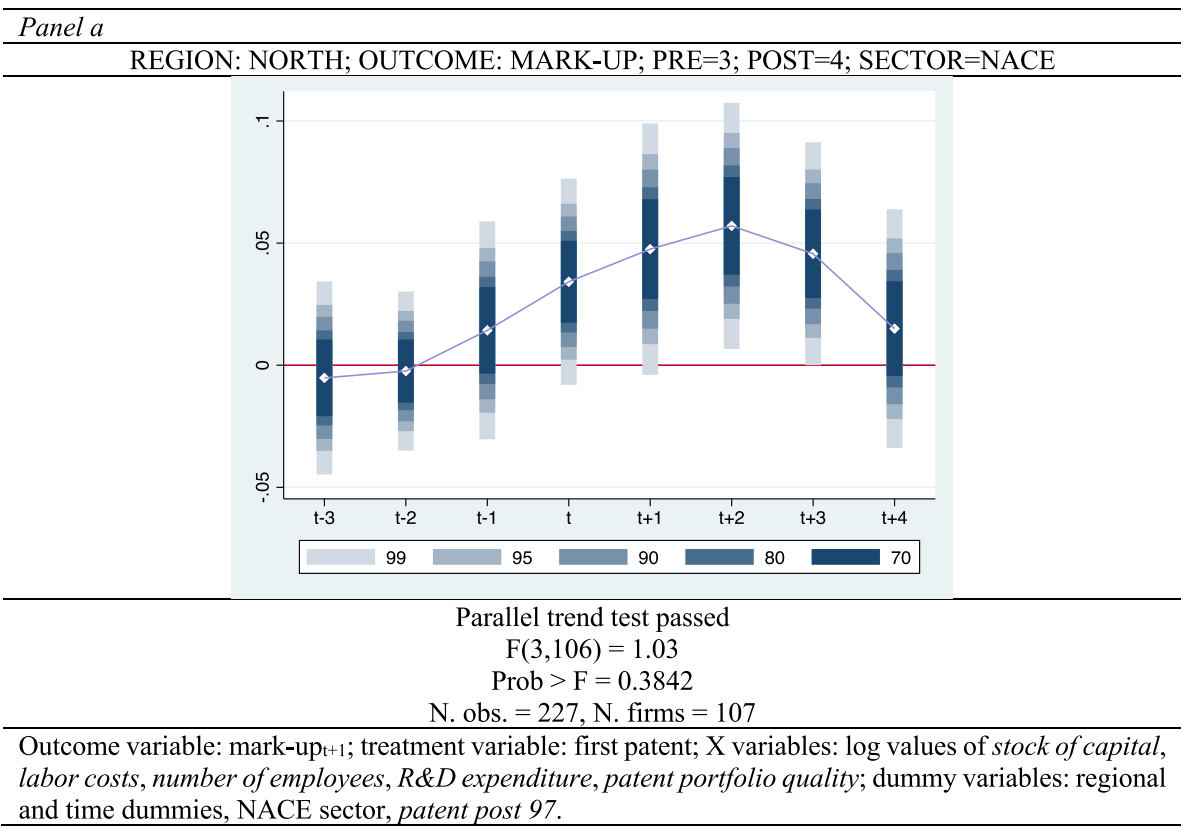

Fig. 2 Dynamic difference-in-differences 
In the second step of our investigation, we analyze the impact of academic patenting on firm performance compared to non-academic patents: we test if firms owning academic patents perform better in terms of market positioning measured by mark-up (hypothesis H1), and worse in terms of profitability (hypothesis H2). In this case, our treatment variable is a dummy variable that takes value 1 from the year in which firm $i$ first owns a patent (by priority date) that has among its inventors at least one academic scientist, and zero otherwise. Again, the outcome variables (mark-up, ROA, and ROE) are forwarded at time $t+1$, and the regressors are the same as in the previous exercise. We also control for patent technology field (relying on the International Patent Classification).

Figure 3 shows the propensity score matching results regarding the comparison between companies filing and companies not filing academic patents on the following outcomes: mark-up, ROA, and ROE.

For all the three matching exercises, we perform a propensity-score nearest-neighbor matching approach which is generally robust as fully data-driven. For matching to be an unbiased estimation of the average treatment effect on the treated (ATET), three assumptions are needed: (1) good overlap, (2) good balancing, (3) robustness to the possible presence of unobservable selection. We show that, given the observable confounders considered, the overlap is good as the pre-matching distributions of the propensity score of treated and untreated units take values on a large common set (see Fig. 3). Moreover, the balancing is good as well, as the post-matching distributions of the propensity score of treated and untreated units coincide pretty perfectly, thus assuring good overall balancing (as visible in the left panel of Fig. 3). Same results hold for each observable confounder singularly considered. The variable-by-variable balancing test for the mark-up outcome is reported in Table 6.

As for assumption (3), it is known from the literature that there is no possibility to test matching robustness to unobservable selection with a proper statistical test. In the literature, however, such robustness is assessed via "sensitivity analysis" to unobservable selection. The most popular test in this direction is the Rosenbaum (1987) test based on the Wilcoxson rank statistic. Assuming as test's null hypothesis that the baseline estimated matching was able to restore randomization in an ex-post fashion, this test perturbates the initial matching by allowing for the presence of an increasingly severe unobservable confounder. If, for larger departure from randomization due to the unobservable confounder, initial results are overturned at a high level of non-randomization, it would mean that results are robust, otherwise that results are poorly robust. This conclusion is independent of the fact that this unobservable exists (as it may also not exist at all), but it shows to what extent a matching can be reliable when the presence of an unobservable confounder can be pervasive. 


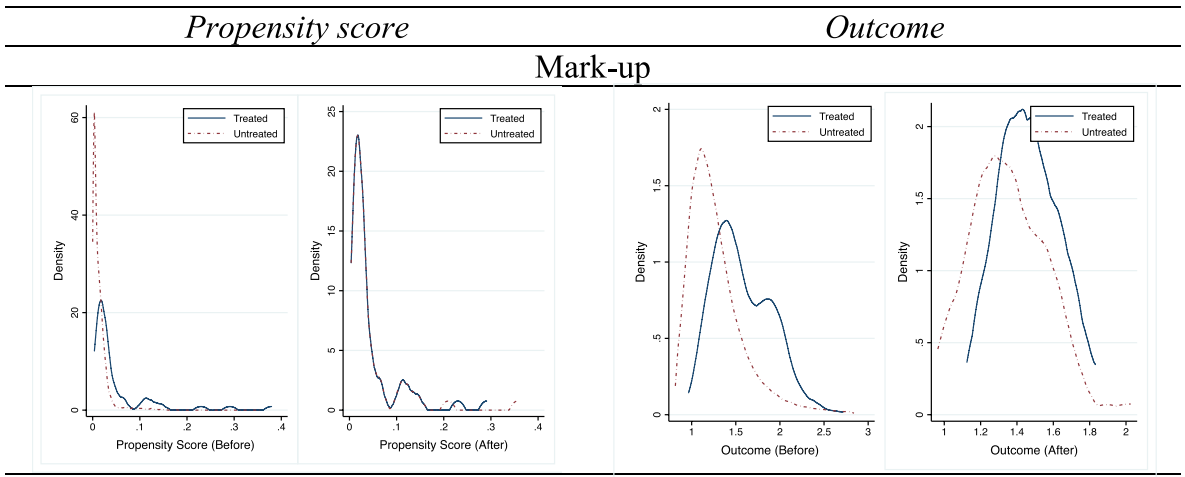

ATET $=0.094^{* * *}$

Obs. of treated (common support) $=55$;

Obs. of untreated $=2,279$

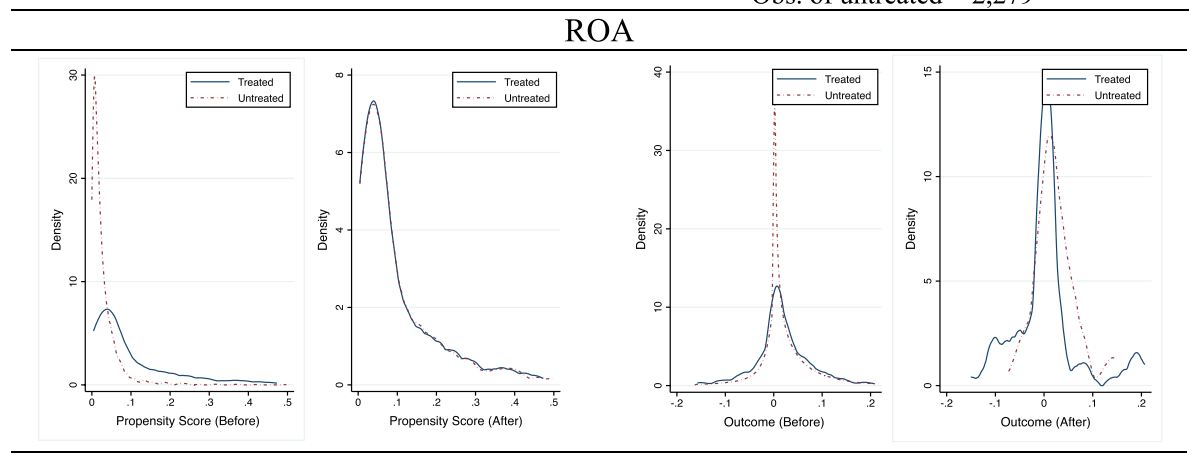

ATET $=-0.018^{*}$

Obs. of treated (common support) $=75$;

Obs. of untreated $=2,479$

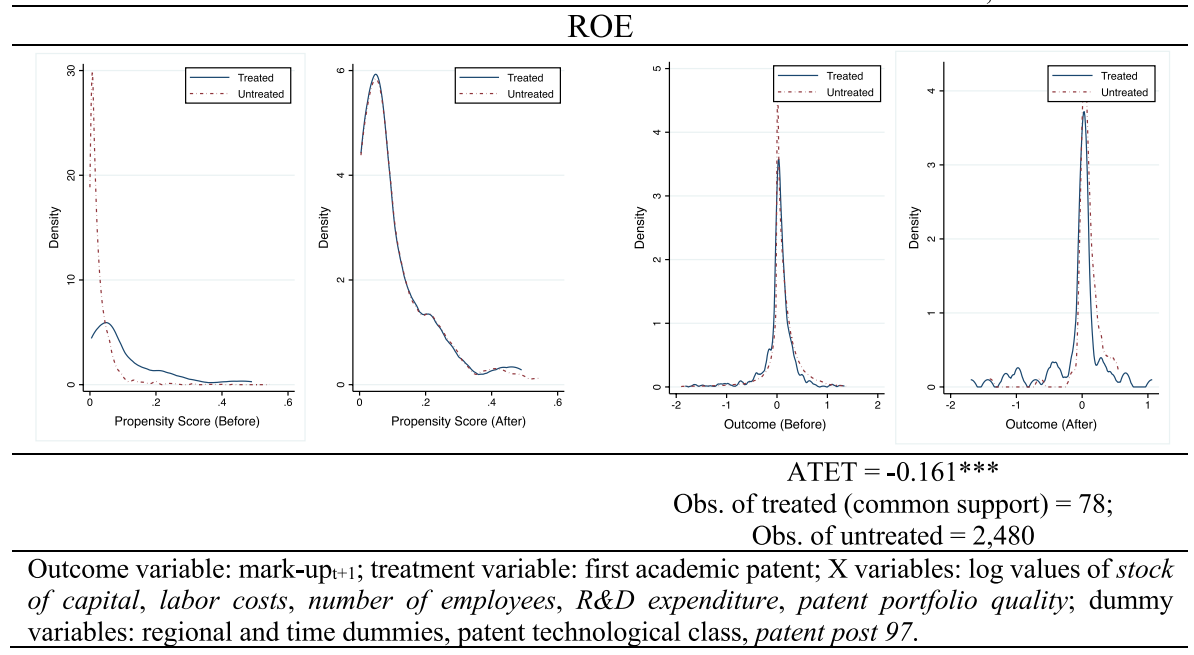

Fig. 3 Propensity score matching results for company-owned academic patents 
Table 6 Variable-by-variable balancing test or the mark-up outcome before and after propensity-score nearest-neighbor matching

\begin{tabular}{|c|c|c|c|c|c|c|c|c|}
\hline \multirow[t]{2}{*}{ Variable } & \multirow{2}{*}{$\begin{array}{l}\text { Unmatched } \\
\text { matched }\end{array}$} & \multirow{2}{*}{\multicolumn{2}{|c|}{$\begin{array}{l}\text { Mean treated } \\
\text { control }\end{array}$}} & \multirow[t]{2}{*}{$\%$ Bias } & \multirow{2}{*}{$\begin{array}{l}\text { \% Reduct } \\
\mid \text { bias| }\end{array}$} & \multicolumn{2}{|l|}{$t$ test } & \multirow[t]{2}{*}{$\mathrm{V}(\mathrm{T}) / \mathrm{V}(\mathrm{C})$} \\
\hline & & & & & & $\mathrm{t}$ & $\mathrm{p}>|\mathrm{t}|$ & \\
\hline \multirow[t]{2}{*}{ _pscore } & $\mathrm{U}$ & 0.0694 & 0.02347 & 82.4 & & 10.51 & 0.000 & $5.62 *$ \\
\hline & M & 0.0638 & 0.06379 & 0.0 & 100.0 & 0.00 & 0.999 & 1.00 \\
\hline \multirow[t]{2}{*}{ Stock of capital } & $\mathrm{U}$ & 14.818 & 15.017 & -10.9 & & -1.05 & 0.292 & $2.56^{*}$ \\
\hline & M & 14.769 & 14.978 & -11.5 & -5.8 & -0.61 & 0.543 & $2.63 *$ \\
\hline \multirow[t]{2}{*}{ Labor costs } & $\mathrm{U}$ & 14.316 & 14.626 & -27.6 & & -2.18 & 0.030 & 1.29 \\
\hline & M & 14.276 & 14.452 & -15.6 & 43.4 & -0.79 & 0.429 & 1.01 \\
\hline \multirow[t]{2}{*}{ Number of employees } & $\mathrm{U}$ & 3.8089 & 4.1784 & -32.8 & & -2.63 & 0.009 & 1.38 \\
\hline & M & 3.7698 & 3.9372 & -14.9 & 54.7 & -0.76 & 0.450 & 1.12 \\
\hline \multirow[t]{2}{*}{$R \& D$ expenditure } & $\mathrm{U}$ & 10.647 & 10.119 & 30.3 & & 2.29 & 0.022 & 1.08 \\
\hline & M & 10.623 & 10.637 & -0.8 & 97.3 & -0.05 & 0.961 & $1.82 *$ \\
\hline \multirow[t]{2}{*}{ Patent portfolio quality } & $\mathrm{U}$ & 0.0750 & 0.0543 & 11.7 & & 0.92 & 0.358 & 1.29 \\
\hline & M & 0.0710 & 0.0436 & 15.5 & -32.9 & 0.95 & 0.346 & $3.15^{*}$ \\
\hline
\end{tabular}

Outcome variable: mark-up $\mathrm{t}_{\mathrm{t}+1}$; treatment variable: first patent; $\mathrm{X}$ variables: log values of stock of capital, labor costs, number of employees, $R \& D$ expenditure, patent portfolio quality; dummy variables: regional and time dummies, NACE sector, patent post 97

We performed the Rosenbaum test for the matching for the "mark-up" outcome showing that we overturn our positive result on the mark-up at a level of departure from non-randomization (due to unobservable selection) of around 37\%: it is an extremely high value, thus concluding that our matching results are robust. Table 7 sets out this result.

In sum, previous tests allow us to give a causal interpretability to our matching findings. ${ }^{12}$

Results on the outcomes (right panel of Fig. 3) clearly show a positive effect of the academic patenting activity on mark-up, that is, a positive effect on the capacity of companies with academic patents in their portfolio to gain ground in the product market because of the ability to set prices above the average competitive pricing floor. Remarkably, the results on profitability indicate moderately lower profitability of companies with academic patents. Our results on ROA index are significantly corroborated by the robustness analysis conducted using the ROE index.

How can we interpret these results? A possible explanation is that larger knowledge breadth and depth of academic patents that owing firms can exploit—while increasing their market power as measured by the mark-up_might decrease their rate of profitability in the short run. Indeed, especially in the short run, academic patents (ownership and exploitation) may be costly: in the short run they imply additional investments and fixed costs (see Sect. 6.1 on investment costs and profitability measures), as well as some other adjustment costs that can affect profitability indices. Thus, our results perfectly complement each other and return an articulated perspective on the effects of academic patents presence in firms' portfolio.

\footnotetext{
12 Results on ROE and ROA are similar. For sake of brevity, we do not report all previous information for these outcomes. However, it is available upon request.
} 
Table 7 Rosenbaum sensitivity test after matching. Bounds for delta ( $\mathrm{N}=55$ matched pairs): Dep. Var. "Mark-up"

\begin{tabular}{lllllll}
\hline Gamma & sig+ & sig- & t-hat+ & t-hat & CI+ & CI- \\
\hline 1 & 0.004365 & 0.004365 & 0.108755 & 0.108755 & 0.031899 & 0.182108 \\
1.01 & 0.004793 & 0.00397 & 0.108038 & 0.109778 & 0.031405 & 0.183309 \\
1.02 & 0.005253 & 0.00361 & 0.107048 & 0.111008 & 0.030453 & 0.185438 \\
1.03 & 0.005745 & 0.003283 & 0.106091 & 0.112247 & 0.029749 & 0.186611 \\
1.04 & 0.006272 & 0.002984 & 0.104403 & 0.114041 & 0.027446 & 0.186896 \\
1.05 & 0.006834 & 0.002712 & 0.103742 & 0.114718 & 0.024556 & 0.188853 \\
$\ldots$ & & & & & & \\
1.35 & 0.046443 & 0.000145 & 0.071511 & 0.145493 & -0.013289 & 0.221389 \\
1.36 & 0.048683 & 0.000131 & 0.071047 & 0.146786 & -0.014055 & 0.22259 \\
1.37 & 0.050988 & 0.000119 & 0.070283 & 0.146998 & -0.014767 & 0.224069 \\
1.38 & 0.05336 & 0.000108 & 0.069745 & 0.147338 & -0.01532 & 0.224333 \\
1.39 & 0.055798 & 0.000098 & 0.067927 & 0.148125 & -0.016398 & 0.227113 \\
1.4 & 0.058302 & 0.000088 & 0.066972 & 0.148675 & -0.016865 & 0.227314 \\
$\ldots$ & & & & & & 0.2736768 \\
1.97 & 0.29276 & $2.80 \mathrm{E}-07$ & 0.02515 & 0.188699 & -0.066975 & 0.270769 \\
1.98 & 0.297933 & $2.50 \mathrm{E}-07$ & 0.023617 & 0.189414 & -0.069007 & 0.271114 \\
1.99 & 0.303119 & $2.30 \mathrm{E}-07$ & 0.023276 & 0.189965 & -0.069847 & 0.271162 \\
2 & 0.308318 & $2.10 \mathrm{E}-07$ & 0.022536 & 0.190629 & -0.070013 & 0.272227 \\
\hline & & & & & &
\end{tabular}

Finally, we report on the ATET(x) distribution obtained through a regression-adjustment approach (see Fig. 4) to complement the matching results in Fig. 3.

Defined as the average effect on treated companies conditional on the pre-specified covariates $\mathbf{X}$, ATET $(X)$ measures firm-specific (average) effect. Thus, plotting its distribution is meaningful. Based on the law of iterated expectations, $\operatorname{ATET}(X)$ distributions are centered at ATET and can be interpreted as the distributions of firm-specific idiosyncratic (average) effects. Results show that the distribution for all outcomes was well bell-shaped, with the mark-up distribution presenting, however, larger frequencies for positive values. A longer right tail also characterizes this distribution, showing that a bunch of companies holding academic patents are responsible for the overall positive effect. This phenomenon may reflect the elitist nature of academic patenting, involving few specialized companies, such that reliance is possibly more on basic research and cutting-edge scientific solutions. The effect distribution for ROA is much more centered around zero, whereas the ROE presents higher frequencies on negative effects. These findings confirm the matching results on these two outcomes.

\section{Discussion and final remarks}

This paper investigates the impact of company-owned academic patents on firms' market power and profitability. Academic patenting as a University-Industry interaction mode (either as result of co-inventing activity or as holding or acquisition of academic patents) combines basic research and applied technological orientation. The economic literature 

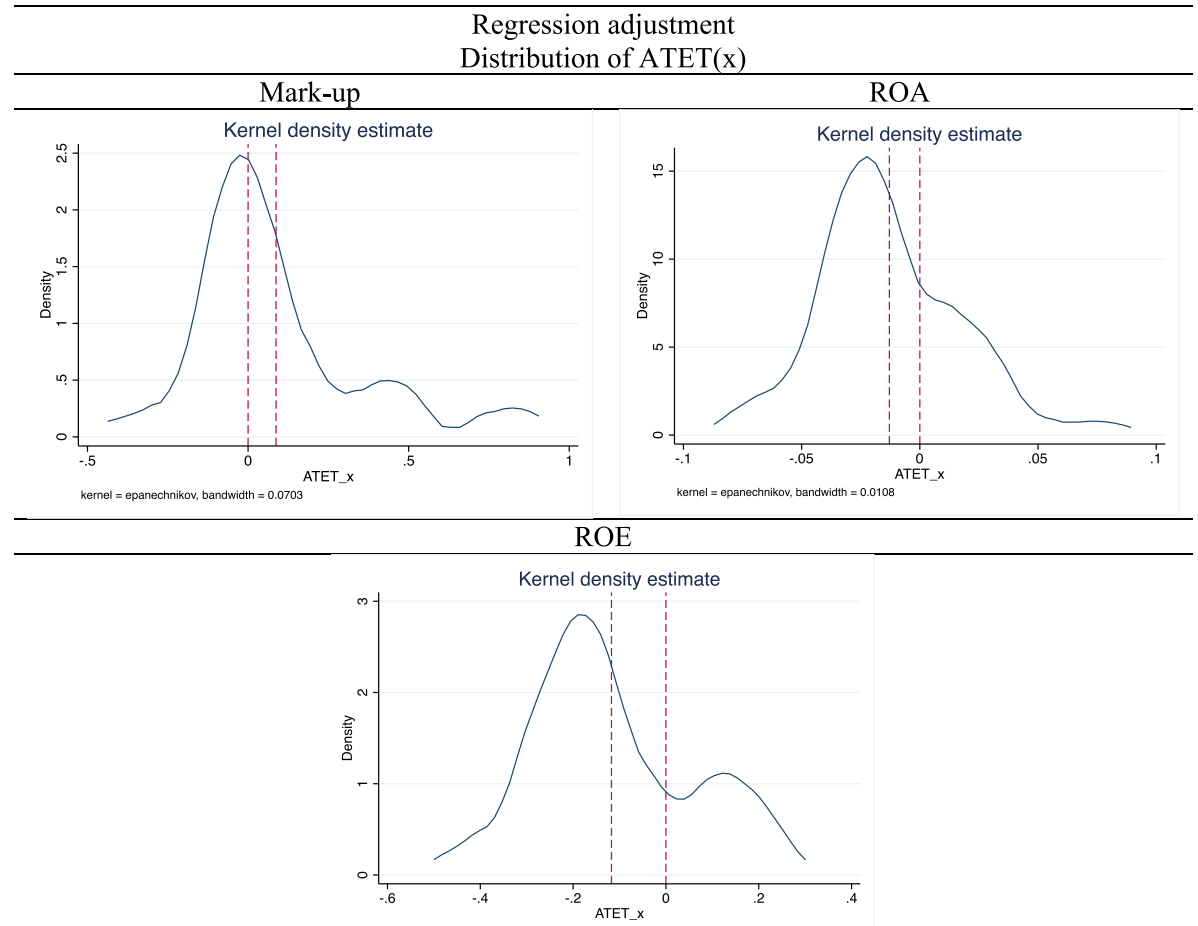

kernel $=$ epanechnikov, bandwidth $=0.062$

Outcome variable: mark-up $\mathrm{t}_{\mathrm{t}+1}$; treatment variable: first academic patent; X variables: log values of stock of capital, labor costs, number of employees, $R \& D$ expenditure, patent portfolio quality; dummy variables: regional and time dummies, patent technological class, patent post 97.

Fig. 4 Regression adjustment

supports the idea that academic patenting allows firms to enlarge their capability to explore and develop new solutions.

The comparative analysis of qualitative characters of patents in firms' portfolio highlights that academic patents have larger patent scope, number of claims, and citations to non-patent literature. Further, they rely less on previous knowledge. Overall, academic patents are characterized by larger breadth and depth of knowledge, and show higher potential knowledge spillovers in technology.

On the one hand, this evidence allows formulation of the hypothesis of positive effects of academic patenting on a firm's innovative performance and market power; on the other hand, the impact of academic patenting on firms' economic performance is more open and controversial for several reasons: (i) sectoral and technological heterogeneity of academic patents; (ii) skewness of patents' value distribution as measured by quality indices; (iii) longer innovation processes and higher associated costs; and (iv) higher riskiness associated with more radical innovation embedded in academic patents that requires adjustment processes within the firm.

Our descriptive analysis presents an interesting picture of the firms owning academic patents and benefit of the associated knowledge spillovers. We detect a relevant group of small firms well-structured in terms of tangible and intangible capital that display a critical potential for successful innovative activities. 
We consider all these aspects to test the two main hypotheses. First, can business-owned academic patents allow firm to get stronger market power given their higher technological potential? Second, how does the commercialization of these inventions impact on firm's economic returns? However, because these patents are usually associated with higher risks and costs, economic results can be more uncertain. Based on the economic literature, we expect a significant difference in terms of economic returns over different time horizons because positive economic returns are more likely in the long run. Given the data availability, in our analysis, we could investigate only the short run effect and distinguish three types of performance: market power (mark-up); general profitability (ROA), which also accounts for high costs associated with patents with high technological content; and ROE to corroborate our results.

We conducted our empirical investigation by using a matching procedure, thus avoiding selection bias problems associated with the characteristics of the sample detected in the descriptive analysis. We tested for differences in firm performance by comparing firms that hold academic patents and, thus, benefit of academic knowledge spillovers, with firms that do not access academic research through the ownership and exploitation of academic patents. This type of analysis allows to fill a gap in the literature mainly imputable to the lack of good data that only recently have become available for a limited number of countries, including Italy.

The potential for better positioning in the market, associated with a temporary monopoly, clearly characterizes firms that own academic patents in their portfolios. These results corroborate the idea that academic patents transfer important knowledge spillovers to firms. Indeed, in our sample, academic patents are largely owned by micro and small enterprises and, according to the literature (Oakey 1995; Audretsch and Thurik 2001; Oakey 2003, 2011), these firms can get important benefit from knowledge spillovers compared with firms of larger dimensions holding a large patent portfolio. This potential is not reflected in better economic results in a linear manner because the implementation of this type of invention implies larger risks and costs and, therefore, higher heterogeneity in terms of performance. Academic patents can positively affect economic returns given their larger scope which can determine a larger number of possible applications. However, this higher potential implies larger costs and investments that require longer time for recovery. Indeed, if we measure profitability in terms of ROA and ROE, short run performance of firms owning academic patents result to be poorer with respect to firms holding only corporate patents. This negative effect can be determined by higher cost that, for instance, may derive from different sources: new fixed costs; collaboration costs as a result of joint research; cost of acquisition when academic patents are outsourced; adjustment costs to improve the firm's absorptive capacity if academic knowledge is far from firm's competences.

Another important aspect concerns the time lag regarding the correct observation of the difference between firms that hold academic patents and those that do not. In our sample, we have a critical amount of pharmaceutical companies for which a significant time lag is observed between patent filing and marketable products; therefore, one limit of our analysis is determined by the investigation of short-term effects (a one-year lag) for profitability measures. Indeed, we might expect that a long-term effect could reverse what we detected in the short run.

Based on these results and considering the longer time horizon required for academic patents to create a marketable product, we derive some policy implications. As aforementioned, fiscal and financial policies to support research and industrial innovation have recently attributed more importance to the presence of firms' patent portfolios. In particular, three lines of Research Development and Innovation policy in Italy are connected with 
firms patenting activity: (i) a procedure available to micro-, small-, and medium-sized firms (National Innovation Fund) that grants access to funding innovative projects based on patent use, and the allocated financial resources are in the form of risk capital and debt financing; (ii) a program promoted by the Ministry of Economic Development (Innovation package) that rewards firms that apply for national and international level patenting modulated on the basis of the number of patents, patents' families, and country of extension. It also offers grants for the commercialization of patented innovations; the (iii) tax relief (Patent Box) for revenues from the use of intangible assets output of research activity.

The rationale of these policies is to support the costs of research activities that would result in critical and exclusive economic value to the innovating firms. In terms of policy, possible consequences of our analysis could be the introduction of a focus on the presence of academic patents in the firms' portfolio. Indeed, a set of economic incentives dedicated to companies holding academic patents could support improvements in the integration between basic and applied research by assuming that higher riskiness and longer innovation processes may prevent firms from obtaining a good market position and adequate returns.

Funding Open Access funding provided by Università degli Studi Roma Tre.

Open Access This article is licensed under a Creative Commons Attribution 4.0 International License, which permits use, sharing, adaptation, distribution and reproduction in any medium or format, as long as you give appropriate credit to the original author(s) and the source, provide a link to the Creative Commons licence, and indicate if changes were made. The images or other third party material in this article are included in the article's Creative Commons licence, unless indicated otherwise in a credit line to the material. If material is not included in the article's Creative Commons licence and your intended use is not permitted by statutory regulation or exceeds the permitted use, you will need to obtain permission directly from the copyright holder. To view a copy of this licence, visit http://creativecommons.org/licenses/by/4.0/.

\section{References}

Ackerberg, D. A., Caves, K., \& Frazer, G. (2015). Identification properties of recent production function estimators. Econometrica, 83, 2411-2451.

Ahuja, G., \& Lampert, C. M. (2001). Entrepreneurship in the large corporation: A longitudinal study of how established firms create breakthrough inventions. Strategic Management Journal, 22, 521-543.

Andrews, D., Criscuolo, C., \& Menon, C. (2014). Do resources flow to patenting firms? In OECD Economics Department Working Papers No. 1127.

Artz, K. W., Norman, P. M., Hatfield, D. E., \& Cardinal, L. B. (2010). A longitudinal study of the impact of $\mathrm{R} \& \mathrm{D}$, patents, and product innovation on firm performance. Journal of Product Innovation Management, 27, 725-740.

Audretsch, D. B., \& Thurik, A. R. (2001). What's new about the new economy? From the managed to the entrepreneurial economy. Industrial and Corporate Change, 10(1), 267-315.

Autor, D. (2003), Outsourcing at will: The contribution of unjust dismissal doctrine to the growth of employment outsourcing. Journal of Labor Economics, 21(1).

Beise, M., \& Stahl, H. (1999). Public research and industrial innovations in Germany. Research Policy, 28(4), 397-422.

Belderbos, R., Carree, M., Lokshin, B., \& Veugelers, R. (2004). Heterogeneity in R\&D cooperation strategies. International Journal of Industrial Organization, 22, 1237-1263.

Bloom, N., \& van Reenen, J. (2002). Patents, real options and firm performance. The Economic Journal, 112.

Callaert, J., Van Looy, B., Verbeek, A., Debackere, K., \& Thijs, B. (2006). Traces of Prior Art: An analysis of non-patent references found in patent documents. Scientometrics, 69, 3-20. https://doi.org/10.1007/ s11192-006-0135-8. 
Cerulli, G. (2015). Econometric evaluation of socio-economic programs: Theory and applications. Berlin: Springer.

Cerulli, G., \& Ventura, M. (2019). TVDIFF: Estimation of pre- and post-treatment average treatment effects with binary time-varying treatment using stata. The Stata Journal, 19(3), 551-565.

Crescenzi, R., Filippetti, A., \& Iammarino, S. (2017). Academic inventors: collaboration and proximity with industry. Journal of Technology Transfer, 42, 730-762.

Crespi, G., Geuna, A., Nomaler, Ö., \& Verspagen, B. (2010). University IPRs and knowledge transfer: Is university ownership more efficient? Economics of Innovation and New Technology, 19(7), 627-648.

Czarnitzki, D., Hussinger, K., \& Schneider, C. (2009). Why challenge the ivory tower? New evidence on the basicness of academic patents. Kyklos, 62(4), 488-499.

Czarnitzki, D., Hussinger, K., \& Schneider, C. (2011). Commercializing academic research: The quality of faculty patenting. Industrial and Corporate Change, 20, 1403-1437.

Czarnitzki, D., Hussinger, K., \& Schneider, C. (2012). The nexus between science and industry: Evidence from faculty inventions. The Journal of Technology Transfer, 37(5), 755-776.

Dasgupta, P., \& David, P. (1994). Towards a new economics of science. Research Policy, 23(5), $487-521$.

De Loecker, J., \& Warzynski, F. (2012). Markups and firm-level export status. The American Economic Review, 102(6), 2437-2471.

Dosi, G. (1988). Sources, procedures, and microeconomic effects of innovation. Journal of Economic Literature, 26, 1120-1171.

Faems, D., Van Looy, B., \& Debackere, K. (2005). Interorganizational collaboration and innovation: Toward a portfolio approach. Journal of Product Innovation Management, 22, 238-250.

Fleming, L., \& Sorenson, O. (2004). Science as a map in technological search. Strategic Management Journal, 25, 909-928.

Gagliardi, L., Marin, G., \& Miriello, C. (2016). The greener the better? Job creation effects of environmentally-friendly technological change. Industrial and Corporate Change, 25(5), 779-807.

Geuna, A., \& Rossi, F. (2011). Changes to university IPR regulations in Europe and the impact on academic patenting. Research Policy, 40(8), 1068-1076.

Giunta, A., Pericoli, F. M., \& Pierucci, E. (2016). University-industry collaboration in the biopharmaceuticals: The Italian case. The Journal of Technology Transfer, 41, 818-840.

Grabowski, H. G., Vernon, J. M., \& Di Masi, J. A. (2002). Returns on research and development for 1990s new drug introductions. PharmacoEconomics, 20 (Supplement 3), 11-29.

Hagedoorn, J., Link, A. N., \& Vonortas, N. S. (2000). Research partnerships. Research Policy, 29, $567-586$.

Hall, B. H., \& Haroff, D. (2012). Recent research on the economics of patents. In NBER working paper No. w17773.

Hall, B. H., Link, A. N., \& Scott, J. T. (2003). Universities as research partners. Journal of Economic Studies, 85, 485-491.

Hanel, P., \& St-Pierre, A. (2002). Effects of R\&D spillovers on the profitability of firms. Review of Industrial Organization, 20(4), 305-322.

Henderson, R., Jaffe, A. B., \& Trajtenberg, M. (1998). Universities as a source of commercial technology: a detailed analysis of university patenting, 1965-1988. Review of Economics and Statistics, 80(1), 119-127.

Kochenkova, A., Grimaldi, R., \& Munari, F. (2016). Public policy measures in support of knowledge transfer activities: A review of academic literature. The Journal of Technology Transfer, 41, 407-429.

Leoncini, R., Marzucchi, A., Montresor, S., Rentocchini, F., \& Rizzo, U. (2019). Better late than never: The interplay between green technology and age for firm growth. Small Business Economics, 52, 891-904.

Lester, R. K., \& Piore, M. J. (2004). The missing dimension. Cambridge, MA: Harvard University Press.

Liberati, D., Marinucci, M., \& Tanzi, G. M. (2016). Science and technology parks in Italy: Main features and analysis of their effects on the firms hosted. The Journal of Technology Transfer, 41, 694-729.

Lissoni, F. (2012). Academic patenting in Europe: An overview of recent research and new perspectives. World Patent Information, 34(3), 197-205.

Lissoni, F., \& Montobbio, F. (2015). The ownership academic patents and their impact. Evidence from five European countries. Revue Economique, 66(1), 143-171.

Lissoni, F., Pezzoni, M., Potì, B., \& Romagnosi, S. (2013). University autonomy, the professor privilege and academic patenting: Italy, 1996-2007. Industry and Innovation, 20(5), 399-421.

Ljungberg, D., Bourelos, E., \& McKelvey, M. (2013). Academic inventors, technological profiles and patent value: An analysis of academic patents owned by Swedish-based firms. Industry and Innovation, 20, 473-487. 
Lotti, F., \& Marin, G. (2013). Matching of PATSTAT applications to AIDA firms: Discussion of the methodology and results, Questioni di Economia e Finanza, Occasional Paper No. 166, Banca d'Italia.

Mansfield, E. (1995). Academic research underlying industrial innovations: Sources, characteristics, and financing. The Review of Economics and Statistics, 77, 55-65.

Mansfield, E. (1998). Academic research and industrial innovation: An update of empirical findings. Research Policy, 26, 773-776.

March, J. G. (1991). Exploration and exploitation in organizational learning. Organization Science, 2, 71-87.

Nelson, R. R., \& Winter, S. G. (1982). An evolutionary theory of economic change. Cambridge, MA: Harvard University Press.

Oakey, R. P. (1995). High technology new firms: Variable barriers to growth. London: Paul Chapman Publishing.

Oakey, R. P. (2003). Technical entrepreneurship in high technology small firms: Some observations on the implications for management. Technovation, 23, 679-688.

Oakey, R. P. (2011), High technology entrepreneurship, Routledge.

OECD Patent Statistics Manual. (2009). ISBN 978-92-64-05412-7.

Peeters, H., Callaert, J., \& Van Looy, B. (2020). Do firms profit from involving academics when developing technology? The Journal of Technology Transfer, 45, 494-521.

Quatraro, F., \& Scandura, A. (2019). Academic inventors and the antecedents of green technologies. A regional analysis of Italian patent data. Ecological Economics, 156, 247-263.

Rosenbaum, P. R. (1987). The role of a second control group in an observational study: Rejoinder. Statistical Science, 2(3), 313-316. https://doi.org/10.1214/ss/1177013237.

Rosenkopf, L., \& Nerkar, A. (2001). Beyond local search: Boundary-spanning, exploration, and impact in the optical disk industry. Strategic Management Journal, 22, 287-306.

Sampat, B., Mowery, D., \& Ziedonis, A. (2003). Changes in university patent quality after the BayhDole Act: A re-examination. International Journal of Industrial Organization, 21(3), 1371-1390.

Sapsalis, E., van Pottelsberghe de la Potterie, B. V. P., \& Navon, R. (2006). Academic versus industry patenting: An in-depth analysis of what determines patent value. Research Policy, 35, 1631-1645.

Schmoch, U. (2008). Concept of a technology classification for country comparisons: Final Report. World Intellectual Property Organization, Geneva to the World Intellectual Property Organisation, WIPO.

Squicciarini, M., Dernis, H., Criscuolo, C. (2013). Measuring patent quality: Indicators of technological and economic value. In OECD science, technology and industry working papers, Organization for Economic Co-operation and Development: Paris.

Stern, S. (2004). Do scientists pay to be scientists? Management Science, 50(6), 835-853.

Sternitzke, C. (2010). Knowledge sources, patent protection, and commercialization of pharmaceutical innovations. Research Policy, 39(6), 810-821.

Sterzi, V. (2013). Patent quality and ownership: An analysis of UK faculty patenting. Research Policy, 42(2), 564-576.

Sterzi, V., Pezzoni, M., \& Lissoni, F. (2019). Patent management by universities: evidence from Italian academic inventions. Industrial and Corporate Change, 28(2), 309-330.

Trajtenberg, M., Jaffe, A., \& Henderson, R. (1997). University versus corporate patents: a window on the basicness of inventions. Economics of Innovation and New Technology, 5(1), 19-50.

Wagner, S., \& Cockburn, I. (2010). Patents and the survival of internet-related IPOs. Research Policy 39, 214-228.

Publisher's Note Springer Nature remains neutral with regard to jurisdictional claims in published maps and institutional affiliations. 